ABORIGINAL
CALIFORNIA 



\title{
ABORIGINAL CALIFORNIA
}

\author{
Three Studies \\ in Culture History
}

Published for

THE UNIVERSITY OF CALIFORNIA ARCHAEOLOGICAL RESEARCH FACILITY

University of California, Berkeley, 1963 
ORIGINALLY ISSUED IN 1961 . AND 1962 AS NUMBERS 54,55 , AND 56 oF REPORTS OF THE UNIVERSITY OF CALIFORNIA ARCHAEOLOGICAL SURVEY

Manufactured in the United States of America 